\title{
Suscetibilidade de Culex quinquefasciatus após Exposição a ácidos graxos e ésteres metílicos
}

\author{
Melo, A. R. ${ }^{1 *}$; Alves, K. F. ${ }^{1}$; Alves, S. N. ${ }^{1}$; Alves, L. A. R. S. ${ }^{2}$ \\ ${ }^{l}$ LAINS - Laboratório de Insetos e Vetores de Doenças/UFSJ, Divinópolis, MG. \\ ${ }^{2}$ LAFIT - Laboratório de Fitoquímica/UFSJ, Divinópolis, $M G$. \\ *aline_rochamelo@yahoo.com.br
}

\section{Resumo}

O mosquito Culex quinquefasciatus é o principal vetor da filariose bancroftiana na Ásia e na África Ocidental e o único responsável pela transmissão nas Américas. No entanto, esse vetor já tem demonstrado resistência a inseticidas como a Deltametrina (Fersol 25CE), um piretroide isômero cis e o Temefós (Fersol 500CE), um organofosforados comumente utilizados no controle desse inseto. Por isso, há necessidade de busca por novos compostos como ácidos graxos e ésteres metílicos e suas ações larvicidas. Assim o presente trabalho teve o objetivo de analisar a taxa de mortalidade em larvas de $3^{\circ}$ instar de $C$. quinquefasciatus após exposição às doses de 100, 10 e 1 ppm de ácidos graxos e ésteres metílicos. As larvas foram expostas aos compostos em recipientes plásticos contendo $100 \mathrm{~mL}$ de solução e observadas até que virassem adultos. Cada recipiente continha 20 larvas num total de 60 para cada concentração. Após a análise dos resultados observou-se que, em relação ao ácido graxo, a concentração de 100 ppm apresentou 70\% de mortalidade, enquanto nas concentrações de 10 e 1 ppm não houve mortalidade de larvas, chegando à fase adulta. Em relação ao éster metílico foram observados 91,67\%, 8,33\% e 1,67\% de mortalidade nas concentrações de 100, 10 e 1 ppm, respectivamente. Os resultados iniciais revelam o potencial larvicida de ácidos graxos e ésteres metílicos, mas outros estudos ainda devem ser feitos.

Palavras-chave: Culex quinquefasciatus, suscetibilidade, ácido graxo, éster metílico.

\section{Apoio financeiro: CAPES, FAPEMIG, UFSJ.}

